\title{
CRAZY ABOUT SCIENCE
}

\section{THE DIFFICULTY OF MIXING ACCOUNTABILITY AND CAREGIVING}

\author{
SAndra Obiol Francés And Alícia Villar Aguilés
}

The general model for evaluating scientific production fits into the accountability system: a way of measuring scientific output which does not usually acknowledge the presence of gender imbalances in academic institutions. Here we take the need to rethink this system and the indicators it uses to measure productivity and scientific quality, as well as the social conditions in which these activities are measured, as a starting point. In particular, we urge the review of this system, considering the administration of caregiving to dependents, be they young or old, as an example, because it is an unresolved problem that affects scientific work as well as progress in gender equality in university institutions.

Keywords: accountability, scientific production, gender equality, care, inequality.

'Oh, you can't help that,' said the Cat: 'we're mad here.
I'm mad. You're mad.'
'How do you know I'm mad?' said Alice.
'You must be,' said the Cat, 'or you wouldn't have come
here.'
(Lewis Carroll. Alice's adventures in Wonderland, 1865)

The madness and nonsense that pervade Alice's Adventures in Wonderland, a book which celebrated the 150 th anniversary of its first edition in 2015, should perhaps make us wonder if today «we're all $\operatorname{mad} \gg$ in the increasingly fastpaced and measured university environment. The imposition of an accountability model following standard criteria for all disciplines and people, far from leading to the intended objectivity and equality, causes (in our opinion) precarity in the work and life relationships related to science communication and teaching. This precarity is more harmful to groups with a weaker structural position, both in society in general and in university settings, usually understood as spaces for social and positional relationships which function according to their own rules (Bourdieu, 1984/2008).

As members of a university body, we suggest that a reassessment of how accountability may have brought about negative change with regard to the link between scientific workers and their institutions is necessary. This concern moved us to reflect upon how researchers are affected when scientific quality is measured according to a number of results obtained within a defined and accepted framework (for instance, the number of papers published in journals indexed in specific databases). This system, apart

from defending a paradoxical concept of quality which solely consists of a quantifying logic (Herzog, Pecourt, \& Hernàndez, 2015), may also represent an element of gender inequality because there are limitations and pressures in academia that unequally affect the decisions women and men make regarding their personal and professional lives (Hernàndez \& Villar, 2014). The distribution of care responsibilities is one of these limitations.

\section{ACCOUNTABILITY, OR UNDERSTANDING QUALITY AS QUANTITY}

The term accountability first emerged in the business world and then spread to the fields of politics and public institutions. We understand accountability as the relationship in which $\mathrm{A}$ is held accountable for something by $\mathrm{B}$, provided that $\mathrm{A}$ is required to justify their actions to $B$. Therefore, the relationship 
between both parties is clearly unequal: $\mathrm{B}$ is in a position of power with respect to $\mathrm{A}$, and can require answerability (both the obligation to respond and the right to be answered to), as well as enforceability (the ability to formulate requirements and demand their compliance); these relationships may also enable correction and penalisation mechanisms (Boni et al., 2012). In the university context, when B is an institution or organisation (private foundation, company, etc.) which funds research, it will establish accountability rules and, when these are not fulfilled, it can impose a penalty. When B is a private institution, it may establish business-like processes and relationships with the university. These transformations have been the subject of wellknown criticisms, which are emphasised by many universities' current trend towards commercialisation (Bok, 2010) and immersion in the model of academic capitalism (Slaughter \& Leslie, 1997; Slaughter \& Rhoades, 2004).

The spread of the accountability model means that the way research is planned, written, presented, and taught is becoming accelerated. The representation of scholars as people who are devoted to reading books and with time to think today seems distant and quite privileged. Now we assure quality on the basis of responsibility and enhancement, because «a successfully implemented quality assurance system will provide information to assure the higher education institution and the public of the quality of the higher education institution's activities (accountability) as well as provide advice and recommendations on how it might improve what it is doing (enhancement)» (European Association for Quality Assurance in Higher Education [ENQA], 2005/2015). Another debate (too complicated to be addressed here) is what we mean by quality. In any case, the accountability model is consistent with the objective of ensuring quality within the framework of the European Higher Education Area. In this recommendation, «Institutions should assure themselves of the competence of their teachers» (ENQA, 2005/2015, p. 21). To accomplish this goal, «teaching staff and university researcher evaluation procedures» have been established. European quality guidelines also recommend higher education institutions provide their teaching staff with «a supportive environment that allows them to carry out their work effectively» (ENQA, 2005/2015, p. 21). The term effectiveness is not useless, it is in line with the European recommendations which suggest that «higher education, research and innovation play a crucial role in supporting social cohesion,

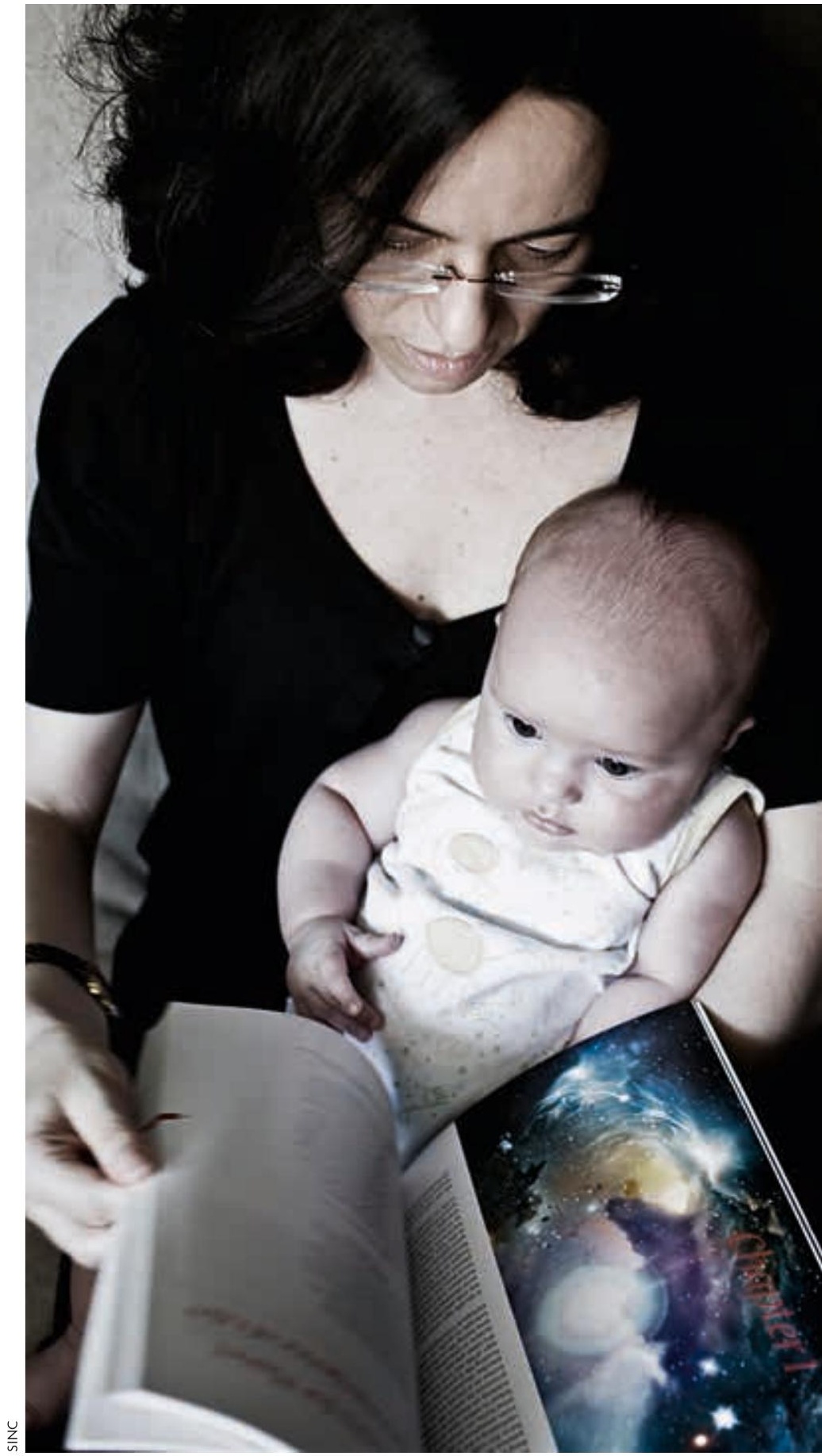

The impossibility of carrying out the many tasks generated in academic fields without taking hours away from one's private life can generate profound and persistent anxiety and exhaustion. In the picture, Alicia Sintes Olives, physics PhD, photographed for the series "The universe looks for conciliation" by the Information and Scientific News Service (SINC).

\footnotetext{
«WE SUGGEST THAT A REASSESSMENT

OF HOW ACCOUNTABILITY MAY HAVE

BROUGHT ABOUT NEGATIVE CHANGE

WITH REGARD TO THE LINK BETWEEN

SCIENTIFIC WORKERS AND THEIR

INSTITUTIONS IS NECESSARY»
} 


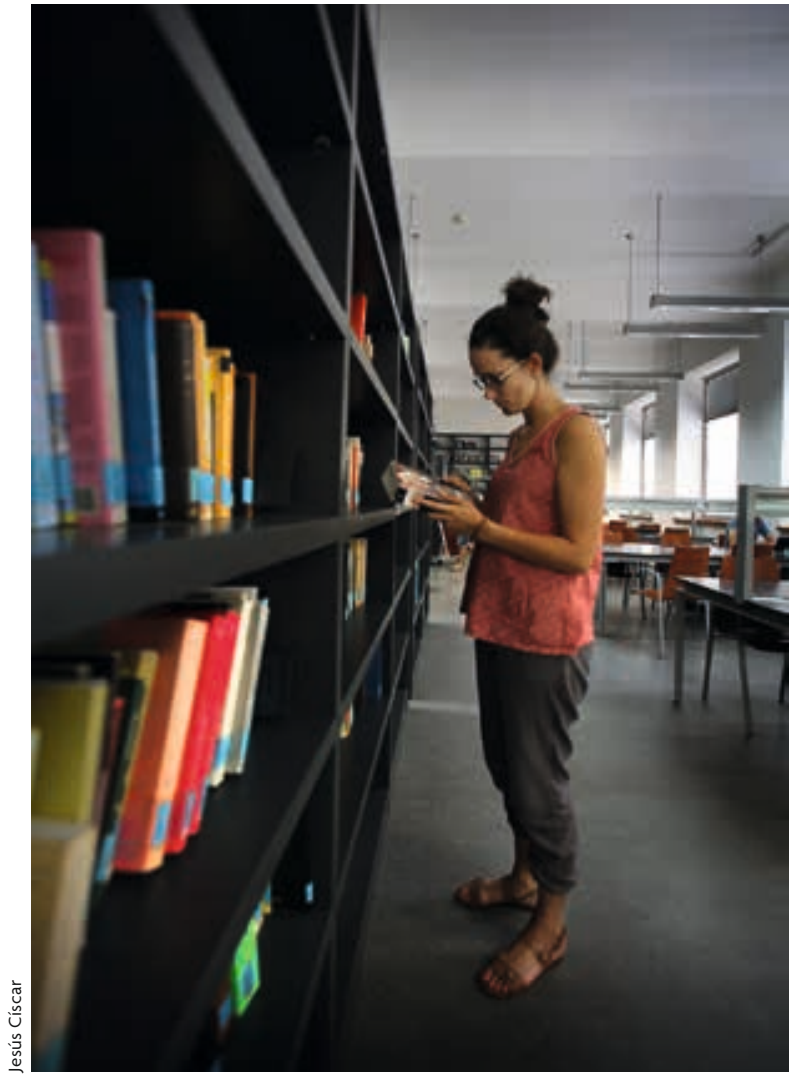

The accountability model promotes an accelerated rate of research planning, writing, and results presentation. University professors who can devote time to reading and reflecting now seem distant and privileged in modern contexts.
What would it mean to turn our lens upon our own labour processes, organisational governance and conditions of production? [...] How might we make links between macro-organisation and institutional practices on the one hand, and experiences and affective states on the other, and open up an exploration of the ways in which these may be gendered, racialised and classed?

(Gill, 2010, p. 229)

These questions are based on a conversation she had with a colleague at a British university, which shows the anxiety generated by the impossibility of carrying out all of the many daily tasks that are common in academia without taking hours from their own private lives:

- [...] I'm doing 16 hour days just trying to keep on top of it. I feel like I'm always late with everything, and my «to do» list grows faster than I can cross things off it. [...] I'm sleeping really badly and it all just feels completely out of control...

- It's the same for me. [...] With me I feel like I'm constantly stealing time from the kids too - I'll go off to check messages in the middle of a game of Monopoly or something. Sometimes I just feel like quitting.

(Gill, 2010, p. 228)

Therefore, the boundaries between paid work and one's family/home dissolve, and the consequence is a deep and persistent exhaustion. In addition, according to Gill, these feelings are embodied in affective experiences that are usually only expressed privately, but if not they are generally silenced and are far from being openly discussed in institutional spaces. This is especially true when careers in research are socially perceived as privileged professions because of their vocational aspect. The affective experiences that are part of everyday work cannot be openly expressed in university offices and spaces, and so they remain hidden: we believe that this silence is one of the reasons the problem remains.

Meanwhile, the use of extensive metrics has prevailed and there is a feeling among scholars that growth and development are linked to «quantified control» (Burrows, 2012). The procedures for evaluating scientific production are close to an «audit culture», expressed in the importance given to «ranking»: improving rank positions in order to attract new talent and funding. However, Burrows also 
claims that, as scholars, we need to better understand ourselves, and that is the precise reason behind this text. Here we ask whether, despite the existence of a formal equality framework, science and academia perpetuate inequality by imposing evaluation processes on their teaching and research staff that are far removed from the social situation surrounding research, regardless of current scientific policies of given governments or the career stage of different researchers at different times.

\section{GENDER BLINDNESS OF THE ACCOUNTABILITY PRINCIPLE}

It has been widely demonstrated that women devote more time to the needs of their family/home and the available data helps to make this difference visible. In Spain men devote more hours a day to paid work (8 hours and 12 minutes, on average) and less to activities grouped under the home/family heading (2 hours and 37 minutes). Whereas, women have - on average - shorter work days (6 hours and 51 minutes) but they spend more time on care tasks (4 hours and 36 minutes). Moreover, the educational level does not introduce significant differences into the time they devote to their family and home: 3 hours and 53 minutes for people with no secondary education or higher secondary education and 3 hours and 29 minutes for people with university studies (National Statistics Institute, 2011). This difference in time distribution helps us to understand women's relationship with the labour market, which is characterised by precarity. Especially in a country like Spain, where well-being depends on the nourishment and strength of family relationships, and mainly involves women.

The figures, however, do not show the variety of care tasks performed in the family environment, or the heterogeneity of circumstances that might substantially change the intensity and rigidity of these care tasks: the families form of coexistence, the point in family life and growth we look at, social class, ethnicity, or the reason family members may need care (a serious illness, for instance), among others. There is, however, a particularly noteworthy common trait: the obligation of managing one's time around the needs of the individual requiring care, often with no control over when and how care is delivered, which can lead to physical and emotional overload for primary caregivers, usually women (Obiol, 2014).

The selflessness required from caregivers clashes with the self-sacrifice that is usually required from employees in modern contexts, especially from scientists. The idea of surrendering «body and soul» to knowledge (Santos, Muñoz, \& Poveda, 2015) is clearly visible in the growing trend of accountabilitybased research models, which develops indicators of scientific production and then incorporates them as criteria for prioritising academic promotions, granting projects and collaborations, distributing budgets, or managing departmental relationships, just to mention some examples. In fact, it is difficult to understand the contemporary construct of research staff academic careers outside this system. Consequently, overlooking the social condition in which evaluated research is produced - or even the conditions in which these indicators were constructed - conflicts with the provision of equal opportunities among researchers. In other words, the lack of nuance incurred in these indicators by not taking into account the time required to provide care, penalises caregiving groups, primarily women.

In fact, despite European recommendations aimed at achieving an effective and competitive academic environment, this setting still seems to be unequal

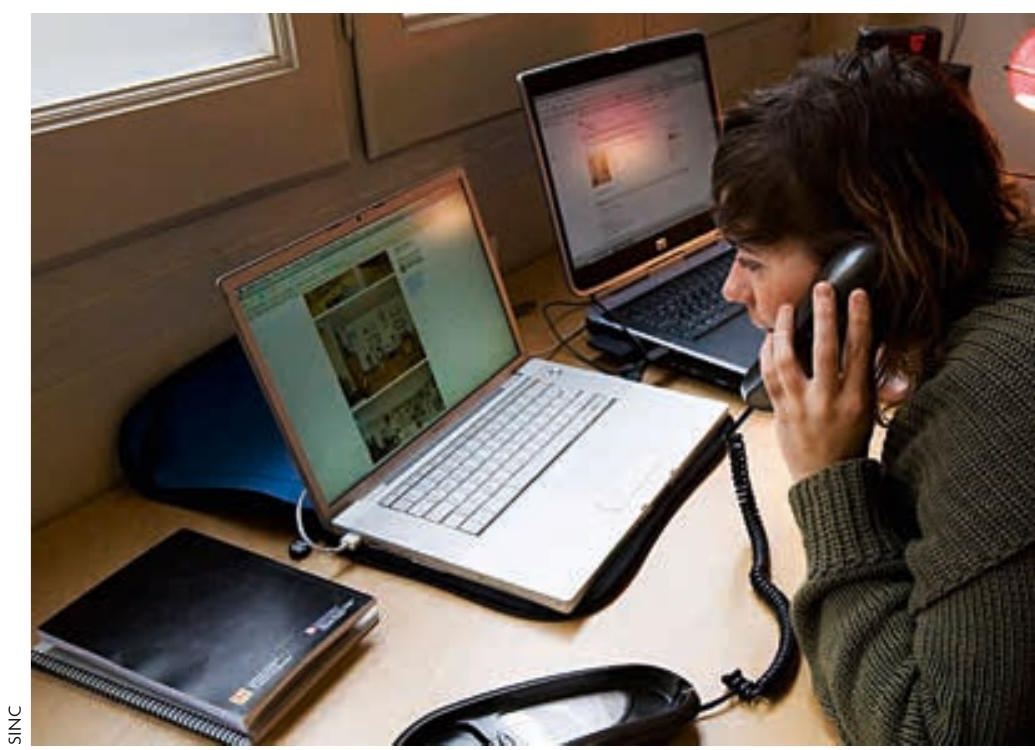

The different amount of time men and women devote to home or family needs helps us to understand women's relationship with the labour market which, for them, is often characterised by precariousness.

«THE OFTEN-MENTIONED GLASS CEILING, WHICH SEEMS DIFFICULT TO BREAK THROUGH, IS EVIDENCE OF THE PERSISTENCE OF GENDER INEQUALITY IN UNIVERSITIES» 


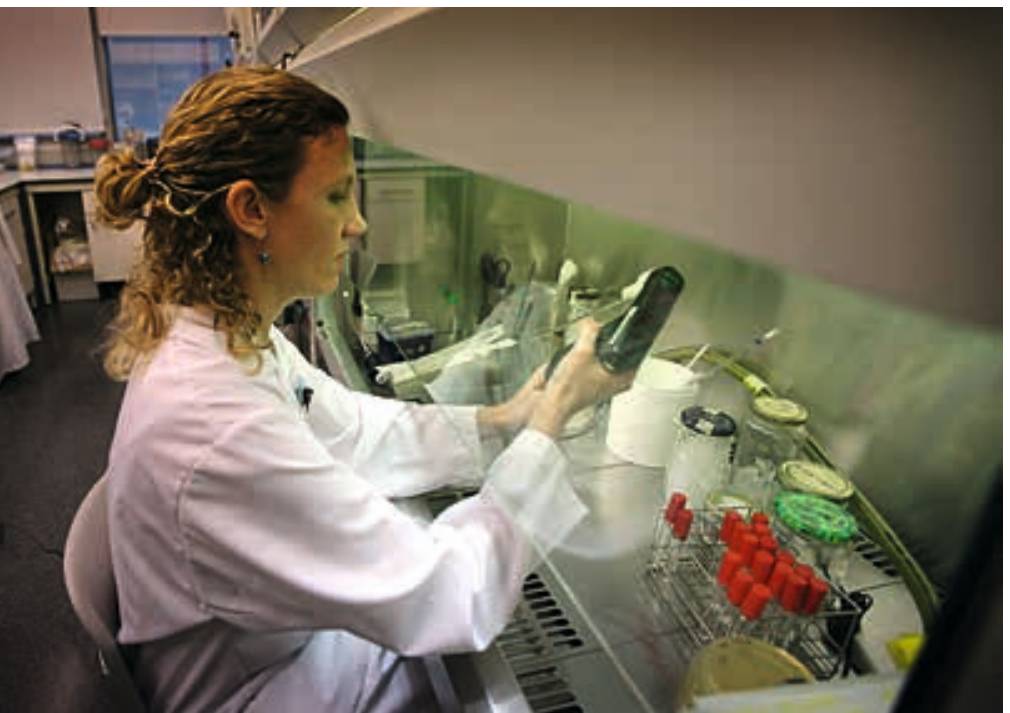

Science and academia, despite the formal equality framework, can perpetuate inequality through the staff teaching and research evaluation processes which are far removed from the social situation surrounding individual's research, the science policies of a particular government, or the career stage of different researchers.

«ACCOUNTABILITY, UNDERSTOOD AS A SYSTEM FOR EVALUATING SCIENTIFIC CAREERS, IS BUILT ON A VERY SPECIFIC IDEA OF WHAT BEING A SCIENTIST IS, AND FITS TRADITIONALLY-MALE PROFILES»

in terms of gender, as shown by the latest data published, precisely, by the European Commission. Women are still underrepresented in the highest academic decision-making positions, with a ratio lower than $40 \%$. The European countries closest to $50 \%$ are Sweden, Luxembourg, and the Netherlands (European Commission, 2016). In Spanish universities, 4 out of every 10 university teachingstaff members are women; however, 8 out of 10 of the highest positions in the academic hierarchy (i.e., full professors) are men, almost half of whom are over sixty years old. The often-mentioned glass ceiling, which seems difficult to break through, is evidence of the persistence of gender inequality in universities.

On the other hand, university staff statistics published by the Spanish Ministry of Education, Culture and Sport show an indicator that could be analysed from the perspective of gender bias: the number of «optimal six-year periods», i.e., the number of six-year periods devoted to research since the reading of an individual's doctoral thesis. This is an indicator that combines time and merits, but does not take into account what happened during this time. According to data from the 2013-2014 school year, the indicator shows that optimal six-year periods are more common in male $(47.8 \%)$ than female $(41.5 \%)$ public professors. Moreover, reading the different categories hints at the possible impact of gender: that is, the difference in the six-year periods obtained by men or women decreases the higher up the hierarchical scale we look. In the full-professorship category, women pass men by two percentage points, while in tenured professors, men are ahead by more than five points. Therefore, we suggest that the hypothesis that a gender bias operates between the levels of tenure and full professorship deserves more careful study.

Indicators show that, despite the increase in the number of women working at universities, they still generally occupy lower positions and have slower careers which include a significant caregiving weight. In fact, a study carried out at the Rovira i Virgili University about their teaching and research staff (Pastor, Belzunegui, Moreno, \& Mañas, 2010) shows that women think that aspects external to the university, such as domestic and reproductive responsibilities, play a role in their professional career, and that women - especially younger women - are more sensitive to the implementation of measures that seek equal opportunities for men and women.

\section{THE NEED TO RETHINK THE CURRENT EVALUATION SYSTEM}

If we accept that research work is measured with quantitative indicators whose results condition the direction and construction of academic careers as inevitable, we should rethink these indicators from the perspective of the social conditions in which this science is produced. This means doing so from a gender perspective, because introducing formal equality elements without first dealing with the interrelationships in the university cannot itself promote equality (Bailyn, 2003).

Accountability, understood as a system for evaluating scientific careers, is built on a very specific idea of what being a scientist is, and fits traditionally-male profiles: extremely long work days during which major distractions (e.g., caregiving) drawing attention away from goal production can be avoided. As previously stated, the schedule for providing care and for dedicating to science sometimes clearly conflict, and the fact that this 
represents a major grievance for women is not recognised. Therefore, we posit that the point is not to consider only certain comparable levels of productivity between women and men, but rather, to look at the transcendent question of how achievement levels affect people; that is, exhaustion, anxiety, or guilt, as explained by Gill (2010), who provides evidence that the introduction of new capitalism practices in university settings (Sennett, 2000) is promoting the «corrosion of character» among scientists. Thus, we should look for new indicators (or find ways to nuance the existing ones) to adapt to the reality of the hundreds of researchers trying to make their jobs compatible with caregiving. Escaping from these indicators' androcentric bias (Carrasco, 2007) would surely promote more equality among researchers.

Caldria, en definitiva, cercar nous indicadors o bé matisar els existents amb la realitat de centenars de persones que investiguen i tracten de fer-ho compatible amb la cura. Fugir del biaix androcèntric d'aquests indicadors (Carrasco, 2007) procurarà de segur un sistema més procliu a aconseguir un major grau d'equitat entre el personal investigador.

In this sense, different proposals have been made; for example, measures designed to decrease gender biases in science and academia which propose not counting years spent caring for dependents when evaluating academic careers or promoting funding for research and teaching innovation projects that achieve gender balance (Izquierdo, 2008). On the other hand, the University of Valencia II Equality Plan proposes analysing and avoiding any harmful effects that regulations have on the careers of those affected. Another piece of good news is that the current Valencian local government Department for Education, Research, Culture and Sport is making some of the requirements for 2016 grant application call more flexible «for those who received maternity or paternity leave granted in accordance with the situations protected by the general Social Security plan, or in the case of individuals who provide care for dependents».

In short, if we truly want an excellent, equitable, and considerate university in terms of its professionals' social conditions, we need the collaboration of all its members without exception. We know, as scientists, that counting is not a neutral activity, but rather that it is done from a very specific social position. Therefore, this standpoint must be considered in order to achieve a gender equality framework - in this case, by considering researchers' caregiving needs beyond the academic field.

\section{REFERENCES}

Bailyn, L. (2003). Academic careers and gender equity: Lessons learned from MIT. Gender, Work and Organization, 10(2), 137-153. doi: 10.1111/1468-0432.00008

Bok, D. (2010). Universidades a la venta. La comercialización de la educación superior. Valencia: Publicacions de la Universitat de València. Boni, A., Peris, J., Acebillo, M., McGee, R. M., Calabuig, C., \& Hueso, A. (2012). Los discursos sobre "accountability" en el sistema de cooperación al desarrollo español. Revista Española de Desarrollo y Cooperación, 29, 199-212.

Bourdieu, P. (2008). Homo academicus. (P. Collier, Trans.). Madrid: Siglo XXI. (Original work published in 1984).

Burrows, R. (2012). Living with the h-index? Metric assemblages in the contemporary academy. The Sociological Review, 60(2), 355-372. doi: 10.1111/j.1467-954X.2012.02077.x

Carrasco, C. (Coord.). (2007). Estadístiques sota sospita: Proposta de nous indicadors des de l'experiència femenina. Barcelona: Institut Català de les Dones.

European Association for Quality Assurance in Higher Education. (2015). Estàndards i directrius per a l'assegurament de la qualitat en l'Espai Europeu d'Educació Superior (Agència per a la Qualitat del Sistema Universitari de Catalunya [AQU]). Barcelona: AQU. (Original work published in 2005). Retrieved from http://www.enqa.eu/indirme/esg/ ESG\%20in\%20Catalan_by\%20AQU\%20Catalunya.pdf

European Commission. (2016). She figures 2015. Gender in research and innovation. Luxembourg: Publications Office of the European Union. doi: $10.2777 / 744106$

Gill, R. (2010). Breaking the silence: The hidden injuries of the neoliberal academia. In R. Ryan-Flood, \& R. Gill (Eds.), Secrecy and silence in the research process: Feminist reflections (pp. 228-244). London: Routledge.

Hernàndez, F. J., \& Villar, A. (2014). La millor pedagogia és la igualtat. Revista Futura, 28, 40-42.

Herzog, B., Pecourt, J., \& Hernàndez, F. J. (2015). La dialéctica de la excelencia académica: De la evaluación a la medición de la actividad científica. Arxius de Ciències Socials, 32, 69-82.

Izquierdo, M. J. (2008). I Congreso Internacional Sesgo de género y desigualdades en la evaluación de la calidad académica. Foros y talleres de trabajo. Bellaterra: Observatori per a la Igualtat; Universitat Autònoma de Barcelona.

National Statistics Institute. (2011). Encuesta de empleo del tiempo 2009 2010. Madrid: INE. Retrieved from http://www.ine.es/dyngs/INEbase/ es/operacion.htm?c=Estadistica_C\&cid=1254736176815\&menu=resultados\&idp $=1254735976608$

Obiol, S. (2014). La transformación de la familia: El caso de los trabajadores del sector textil-confección valenciano. Revista Española de Investigaciones Sociológicas, 145, 127-146. doi: 10.5477/cis/reis.145.127

Pastor, I., Belzunegui, À., Moreno, B., \& Mañas, C. (2010). La igualtat d'oportunitats a la universitat: Les percepcions del PDI. Papers: Revista de Sociologia, 95(2), 457-481. doi: 10.5565/rev/papers/v95n2.19

Santos, J. A., Muñoz, D., \& Poveda, M. M. (2015). En cuerpo y alma: Intensificación y precariedad en las condiciones de trabajo del profesorado universitario. Arxius de Ciències Socials, 32, 13-44 Sennett, R. (2000). La corrosión del carácter: Las consecuencias personales del trabajo en el nuevo capitalismo. Barcelona: Anagrama.

Slaughter, S., \& Leslie, L. L. (1997). Academic capitalism: Politics, policies and the entrepreneurial university. Baltimore (Maryland): The Johns Hopkins University Press.

Slaughter, S., \& Rhoades, G. (2004). Academic capitalism in the new economy. Baltimore (Maryland): The Johns Hopkins University Press.

Sandra Obiol Francés. Professor in the Department of Sociology and Social Anthropology at the University of Valencia (Spain) and member of the Copolis research group. Her research focuses on the processes that create work and personal insecurity, and analysis of single-parent families and family policy. She is the mother of two girls.

Alícia Villar Aguilés. Professor in the Department of Sociology and Social Anthropology at the University of Valencia (Spain) and the current director of the journal Revista de la Asociación de Sociología de la Educación. She researches educational careers, social and educational inequality, and transformations in universities. She is the mother of two girls and a boy. 